\title{
Transnational Radicals: Labour Dissent and Political Activism in Detroit and Turin (1950-1970)
}

\author{
Nicola Pizzolato \\ School of History, Classics and Archaeology, \\ University of Edinburgh \\ E-mail: nicola_pizzolato@hotmail.com
}

\begin{abstract}
Summary: This article investigates the entangled histories of radicals in Detroit and Turin who challenged capitalism in ways that departed from "orthodox" Marxism. Starting from the I950s, small but influential groups of labour radicals, such as Correspondence in Detroit and Quaderni Rossi in Turin, circulated ideas that questioned the Fordist system in a drastic way. These radicals saw the car factories as laboratories for a possible "autonomist" working-class activity that could take over industrial production and overhaul the societal system. They criticized the usefulness of the unions and urged workers to develop their own forms of collective organization. These links were rekindled during the intense working-class mobilization of the late 1960s, when younger radicals would also engage in a dialogue across national boundaries that influenced each other's interpretation of the local context. These transnational connections, well-known to contemporaries but ignored by historians, show how American events and debates were influenced by, and impinged on, distant countries, and how local activists imagined their political identity as encompassing struggles occurring elsewhere.
\end{abstract}

\section{INTRODUCTION}

In $198 \mathrm{I}$, prominent Italian and American economists, sociologists, city administrators, and auto-executives gathered for a high-profile conference sponsored by the Center for European Studies at Harvard University. The explicit purpose of the meeting was to compare two cities experiencing seemingly irreversible economic dislocation and decline: Turin and Detroit. Once the core of the Fordist system founded on the automobile industry, by 1980 the two "motor cities" had become emblematic of the decay of that paradigm of production. The panellists gave an alarming account of capital flight, rapid deindustrialization, deficient public infrastructures, high unemployment rates and uneven urban growth. No longer did residents of Turin and Detroit enjoy some of the highest standards of living available to the Western working class; no longer did 
the automobile market stimulate thriving economies and high levels of capital investment. Automation, outdated facilities, a prolonged season of labour unrest, and finally, the economic recession, had dealt a heavy blow to the chances for industrial and commercial development in these formerly affluent cities. During the conference, city administrators discussed plans to revitalize the waning Fordist cities; the core of their proposals involved modernization of the infrastructures, incentives to attract finance and hi-tech investment, and the diversification of the productive base away from the industrial model that had dominated their past. However, these plans clashed with the problematic state of local finances, the difficulty of attracting private investment and the doubt surrounding government funding. ${ }^{\mathrm{I}}$ What would be the fate of Turin and Detroit?

It was fitting that Italian and American scholars and policy makers should meet at the height of the economic and urban crisis to outline and debate a range of different models of crisis management for the Fordist cities. Even though no-one present alluded to the fact, there was a history of connections between Detroit and Turin, and one that long predated the adverse consequences of the post-industrial era. Detroit and Turin, homes to the most powerful corporations of the twentieth century, had been intertwined in a web of transfers and exchanges of technology, machinery, capital investment, management techniques, and labour relations, not to mention people - managers, engineers, trade-union officials, and lastly, radical thinkers and activists. Today, these links would be called transnational, a term that conveys the image of persons, ideas, and processes moving back and forth across national boundaries. A myriad of variables made Detroit and Turin different, but these transnational connections were the logical consequence of the shared assumption that the two cities were two exemplary offshoots of a global Fordist process.

I came across the wealth of connections between American and Italian labour and political activists, while researching a larger comparative and transnational study on Detroit and Turin in the postwar period. The impact of a single industry and its subcontracting firms on the economic, social, and demographic composition of these cities made them atypical in their respective countries and two cases that seemed to me worth comparing for the historian. The annual automotive output of FIAT increased from 40, I44 vehicles in 1947 , to 623,178 in 1961 , and to $1,391,674$ in 1970. Not only did FIAT produce nearly the totality of automobiles manufactured in Italy, but the great majority of these were assembled in Turin. ${ }^{2}$

I. Richard Child Hill, "La crisi economica e la risposta politica", in Torino-Detroit. Due città a confronto Seminario di studi su crisi economica e risposta politica nelle città dell'Auto (Detroit, I0-13 December 1981) (Turin, 1982), pp. 19-42, 36.

2. Stefano Musso, "Production Methods at Fiat (1930-90)", in Harushito Shiomi and Kazuo Wada (eds), Fordism Transformed: The Development of Production Methods in the Automobile Industry (Oxford, 1995), pp. 243-268, 254, 26I. 
In the post-war period FIAT directly employed 30 per cent of industrial workers in Turin's metropolitan area, and indirectly fuelled an estimated 80 per cent of the local industrial economy. ${ }^{3}$ The importance of car production to the local and national economy and its place in the global automobile market made Turin resemble in some ways its American counterpart. In Detroit, an oligopoly of three firms (GM, Ford and Chrysler: the "Big Three") controlled nearly the totality of the market, even though the share of US automobiles actually manufactured in Detroit declined after $1955 .{ }^{4}$

I find a comparison between postwar Detroit and Turin compelling for at least three reasons. Firstly, it shows how the development and the internationalization of Fordism - a system of regulation of the economy as well as a method of production - set off similar social dynamics in different national contexts. Industrial concentration, mass flows of immigration, unregulated urban sprawl, and inner city decay characterized Fordism in both Detroit and Turin. It was in the motor cities that this system achieved its full potential, while at the same time generating the irreparable effects that led to its demise. Corporations experimented with sophisticated management techniques that rationalized the movement of huge quantities of men and materials. The necessary concentration of production irresistibly drew to the Fordist cities a great army of immigrants which, in Turin and Detroit alike, recomposed the working class and radically altered the social and demographic characteristics of their entire metropolitan areas.

Secondly, Turin and Detroit were hubs of union and social movements that were of national, not local, significance. The Fordist cities were embattled arenas where capital and labour faced each other to determine the balance of power in the most strategic sector of the twentieth-century economy. The result of this confrontation reverberated throughout the respective nations. Quite literally, in the crucial decades of the postwar expansion of the automobile industry, the contractual agreements between automakers' and automobile or (in the Italian case) metalworkers' unions set the standard for what concessions the national working class could hope to extract from industrial employers. The scores of pitched labour battles - such as the sit-down strikes of the r93os (in Detroit) or the I919 Biennio Rosso, "the Two Red Years" (in Turin) of factory occupations - fought in the two cities were celebrated in the radical iconography of their countries. Contemporaries regarded the two motor cities as "laboratories" where social movements formed, dissolved,

3. Stefano Musso, "Il lungo miracolo economico. Industria, economia e società (1950-1970)", in Nicola Tranfaglia (ed.), Storia di Torino. IX Gli anni della Repubblica (Turin, 1999), pp. 49-100, 77 .

4. Thomas J. Sugrue, The Origins of the Urban Crisis (Princeton, NJ, 1996), pp. I25-152. 
and cultivated new tactics and idioms of protest, while they shaped and re-shaped the urban and political contexts.

Finally, the convergences between the Fordist cities were not only the result of parallel developments fostered by the growth of the same industry, but also the outcome of direct connections. From the late I940s to mid-1960s, a process of transfer of technology took place between the American automobile industry and Turin's FIAT. For FIAT's managers, Detroit stood for a system and a philosophy of industrial production that went beyond the boundaries of the American city - a "model" of development - even though they were never blind to their own specific context and to the differences in target consumer demand. In the same period, American unions attempted to influence labour relations at FIAT of strategic importance in the global context of the Cold War - by disseminating a blueprint of industrial relations tested in Detroit and meant to be applicable to European countries. They found apt pupils among the Catholic and social democrat trade unionists, keen to offer a model of industrial relations alternative to that of the communists. Italian trade unionists were sent on "study tours" financed directly by the American Federation of Labor and the Congress of Industrial Organization (the two merged in 1955), or by grants provided by Congress, which often brought them to Detroit. However, the outcome of this collaboration was eventually disappointing for both the Italians and the Americans. ${ }^{5}$

This article investigates one aspect of these networks between the Fordist cities that occurred in antagonism to the relations between managers and trade unionists on the two sides of the Atlantic: the entangled histories of "transnational" radicals in Detroit and Turin who challenged, in theory and practice, capitalism in ways that departed from the "orthodox" Marxist narrative propounded by communist parties.

While a sustained comparison (which remains outside the scope of this article) is promising for the scholar, it was perhaps the transnational aspect that was most cogent for contemporaries. From 1947 - at the same time as company managers and engineers negotiated the technological transfers that would make Turin "the Italian Detroit", and while representatives of the Italian and American labour movements met in countless conferences and study tours to discuss whether American-style collective bargaining should govern industrial relations in the Italian automobile plants - small but influential groups of labour radicals in Detroit and Turin circulated ideas that challenged the Fordist system in a drastic way. Deprived of the copious government resources available to the car

5. See Nicola Pizzolato, "Workers and Revolutionaries on the Shop Floor: The Breakdown of Industrial Relations in the Automobile Plants of Detroit and Turin, 1947-1973" (unpublished Ph.D. thesis, University College London, 2003). 
manufacturers, or even to the unions, radical ideas were transmitted through letters, small-press publications, and, on occasion, men and women who crossed the Atlantic.

In Detroit and Turin, these radicals saw the car factories as the key loci for change - laboratories for a possible "autonomist" working-class activity that could take over industrial production and overhaul the societal system - and urged workers to develop their own forms of collective organization, beyond existing labour organizations. In the volatile political climate of the late i960s, their ideas would greatly influence the actions of a new generation of political activists who exalted industrial conflict in the factories and were determined to force the automobile manufacturers to rethink the model of industrial development that had so far governed the motor cities. From their location in the Fordist cities privileged observatories of the dynamics of that system of production and its societal impact - these younger radicals would also engage in a dialogue across national boundaries which influenced each other's interpretations of the local context. Even though local and national differences needed to be addressed by different political solutions, it mattered for their political identity that they saw themselves as part of a global struggle.

\section{DISCERNING CAPITALISM IN THE MOTOR CITIES}

Labour dissent took different forms in Detroit and Turin, but eventually converged towards a similar critique of organized labour. In the United States, disillusioned activists who had supported or contributed to the growth of industrial unions in the I930s, regarded the postwar purge of the left from the labour movement and the centralization of the bargaining process as evidence that unions were no longer capable of transforming society or empowering workers. In Italy, dissident leftists criticized the inability of the PCI (the Italian Communist Party) and the communist-backed union, the CGIL, to understand the changing nature of work and workers in the automobile plants. As a result, they argued, the "Old Left" failed to counteract the management offensive on the shop floor and was sympathetic to a Fordist "plan" to defuse the class struggle by offering welfare benefits to workers (which was far from being fully realised in I950s and I960s Italy). In both cases, the small but vocal groups that were arguing, in Detroit as in Turin, for a radical new departure in labour relations did so also in opposition to the orthodox idea that the central leadership of a communist party was the key to giving rise to a socialist society. ${ }^{6}$ 
Similarly, in the late I940s United States, many political activists on the left had ceased to believe in the radical potential of the labour movement, which was the target of the ongoing discussion within anti-Stalinist leftist organizations such as the Socialist Workers' Party (SWP), led by James Cannon, and the Workers' Party, led by Max Shachtman. These organizations subscribed in their different ways to Trotsky's concept of "permanent revolution" - the necessity of the urban, industrial proletariat to carry out a revolution through their own political organizations - and spurned both capitalism and Stalinism. Common goals, however, did not sustain a cohesive organization. Within Trotskyism, the constant debate on strategic issues meant that splits and factions were all too common. In the Workers' Party a miniscule but prestigious faction, led by the West Indian intellectual C.L.R. James, went even further in its critique of the capitalist organization of work. James (known then as J.R. Johnson) had originally joined the Trotskysts in London in 1934 while working on his magisterial history of the Haitian revolution, The Black Jacobins (1938), but distanced himself from the group when he started to argue that the Soviet Union had nurtured a system of "state-capitalism" that, similarly to its Western counterpart, rested on the exploitation of workers. ${ }^{7}$ During the I940s, Raya Dunayevskaya (known as Freddie Forest in the party), a Russian émigré intellectual and naturalized American who had once been Trotsky's secretary, had arrived at the same conclusion. They joined forces and formed a faction, later a political group that came to be known as the Johnson-Forest Tendency. Its main leaders and members were based in Detroit.

\section{The Johnson-Forest tendency in Detroit}

By the early I950s, the contention that state or private ownership of the means of production made little difference (as both implied total control of the workforce), and that the Soviet Union was not a workers' state, had driven the group out of Trotskyism altogether. They dropped the name Johnson-Forest, opting for "Correspondence", in reference to the Committees of Correspondence of the American Revolution, and published a monthly newspaper of the same name. Both C.L.R. James and Raya Dunayevskaya were original and profound thinkers, but the group also attracted other talented individuals, notably James Boggs and Grace Lee Boggs, Martin Glaberman, Charles Denby (Si Owens), William Gorman, George Rawick, and others who in their turn earned a nationwide reputation as committed intellectuals and militants. Correspondence was particularly attuned to the problems of autoworkers. James Boggs, Martin Glaberman and Charles Denby had been autoworkers for long periods of their lives and they were able to relate to the actual situation in the 
factories much better that Dunayevskaya or James, who had never had factory jobs. Correspondence was also an interracial organization that comprised whites, blacks, and a Chinese woman: Grace Lee.

The Detroit-based group outlined a critique of American unionism specifically based on the kind of industrial relations to which the United Automobile Workers (UAW) was a partner in the automobile plants. The major themes of this critique were the adverse effect of union bureaucracy on the everyday life of workers and labour's lack of vision and leadership in the working-class struggle. A 1947 pamphlet, The American Worker by Paul Romano (Phil Singer), ${ }^{8}$ was one of the group's most influential early publications. Written just after the trade unions had curtailed a period of intense strike activity, the pamphlet's novelty consisted in presenting, in a worker's own words, a realistic representation of factory work and in decrying the union's failure to address the issues that mattered most, such as the "speed up" (the manufacturer's drive to constantly increase the tempo of production). "Most union leaders do not react to most situations as the rank and file does. It is not rare for a committee man to attempt to persuade a worker not to put in a grievance", observed Romano in order to illustrate the conflicting interests of workers and union leaders. ${ }^{9}$ The union leaders' business-like demeanour and cordiality towards management further demonstrated the divergence between the unions' rhetoric and their practice. Romano also touched upon two important claims: the existence of a latent and spontaneous workers' resistance to the regimented life of the factory, irrespective of any actual union organization; and workers' instinctive ability to organize their work in a more humane, but equally effective way:

Many workers become angry because of the fact that suggestions which they put in are ignored. These suggestions would add to efficiency and also increase production as well as save money. There is a general tendency in all strata of the working class to work in as efficient a manner as possible. ${ }^{10}$

In the pamphlet Punching Out (I952), Glaberman expanded on the constraints of labour bureaucracy. Trade unions were a source of strength, but at the same time the "enemy" of the workers, and the "administrators of capital". Workers, claimed Glaberman, "do not look to the union for the next steps to be taken. They resent and oppose the domination and interference of union bureaucracy." The desire of workers to organize production was already visible in the myriad ways in which they opposed company domination on the shop floor. "Every worker is always looking for ways to make the machine serve him." I The "New Society", a truly

8. Grace Lee Boggs, Living for Change (Minneapolis, I998), p. 62.

9. Paul Romano and Ria Stone, The American Worker (Detroit, MI, I947), p. 22.

Iо. Ibid., p. is.

I I. Martin Glaberman, Punching Out (Detroit, MI, I952), pp. 5, 28. 


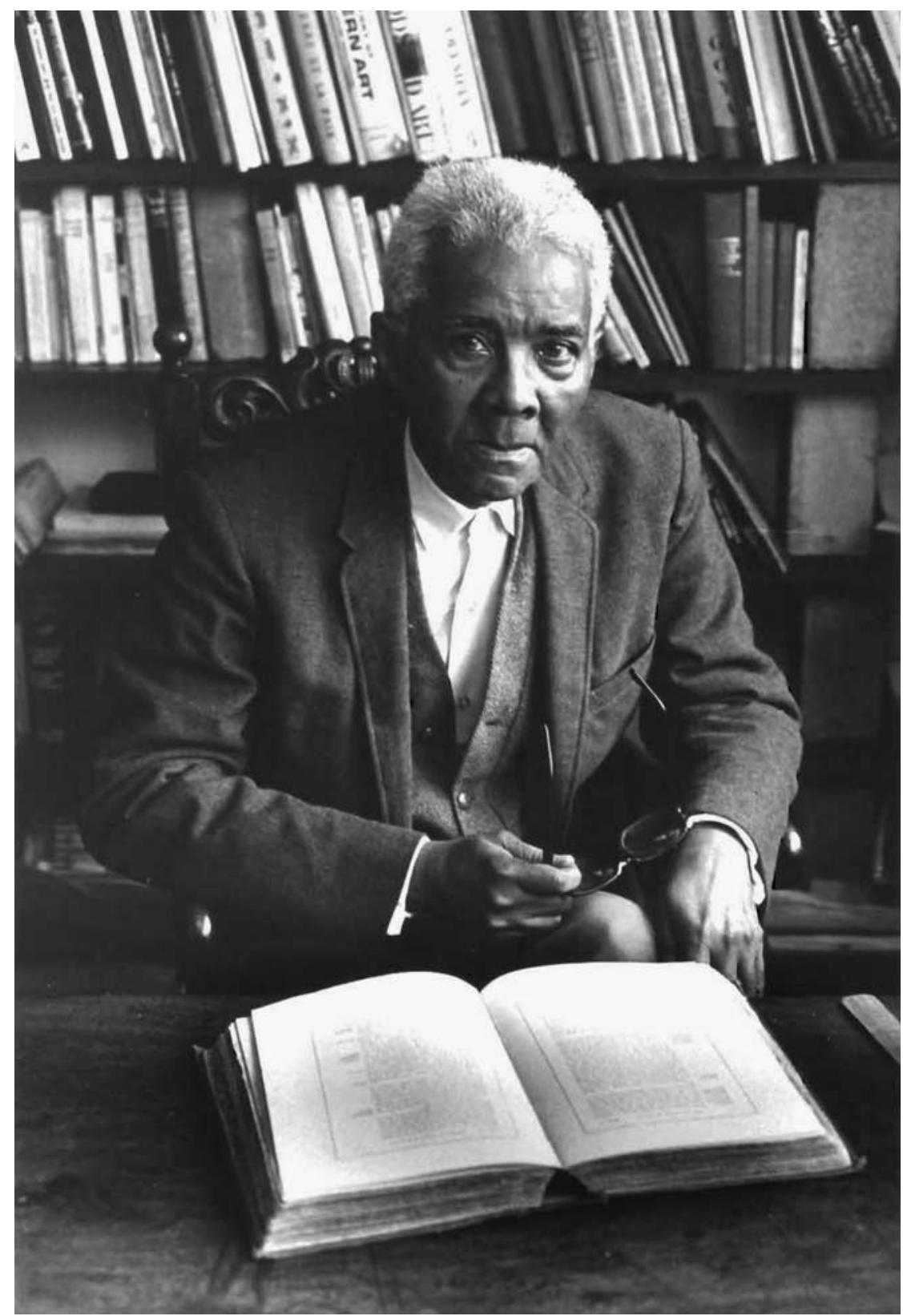

Figure I. At the height of McCarthyism, the US government declared C.L.R. James, the Trinidadian writer, historian and political activist, an undesirable alien. He was one of the transnational figures who most inspired autonomist Marxism in the United States. Photograph: Val Wilmer. Used with permission. 
free one, could only be based on the principle of self-organization, applied both inside and outside the factory. Nationalization amounted only to a different type of domination, as Dunayevskaya and James had argued. It was the task of those who produce to resist supervision and to selforganize production. ${ }^{\mathrm{I2}}$

Correspondence's ability to reach out to workers and students, rather than being restricted to its own narrow circle, was due to its strong belief in giving a voice to the grassroots, and in constantly referring to the everyday experiences of the working class. ${ }^{13}$ Correspondence attracted to its meetings a generation of young radicals whose names later figured in the chronicles of the rank-and-file strikes and in the radical politics of Detroit in the late I960s. ${ }^{\text {I4 }}$ Dan Georgakas, a radical activist who published books and memoirs about that period, remembers that people like James Boggs made a strong impression on the audiences at those meetings, particularly on African Americans like Luke Tripps, Mike Hamlin, General Baker, and Charles Johnson who later led the League of Revolutionary Black Workers. ${ }^{\text {Is }}$

But the magnetism of Correspondence derived also from its eagerness to tackle a decisive issue for Detroit autoworkers and political activists: the racial composition of the working class or, as it was often referred to in the I940s and I950s, the "Negro question". In approaching this problem, Correspondence had drawn inspiration from C.L.R. James's musings on the topic of the black working class and further developed them in reference to the situation in Detroit. As a black West Indian living in the United States between 1938 and 1953, James had come to realise the importance of an autonomous mobilization of African Americans. Since the late i93os James had, at times successfully, persuaded Trotsky and the Socialist Workers' Party to devote more resources to organizing African Americans, "potentially the more revolutionary section of the population" ${ }^{16}$ Ironically, he argued, the "special degradation" of the black proletariat and its exclusion from American capitalism provided them with an autonomous impetus to challenge it. ${ }^{17}$

I2. Ibid., pp. 28, 32 .

I 3. See Rachel Peterson, "Correspondence: Journalism, Anticommunism, and Marxism in i950s Detroit", in Robbie Lieberman and Clarence Long (eds), Anticommunism and the African American Freedom Movement (New York, 2009), pp. I I 5-160.

I4. The contacts occurred in particular when Martin Glaberman started teaching political science at Wayne State University. Interview with Martin Glaberman, July 200I, in the possession of the author. See also, "Revolutionary Optimist - An Interview with Martin Glaberman" available online at: http://www.oocities.com/red_black_ca/glaberman.htm.

is. Dan Georgakas, "Young Detroit Radicals, 1955-1965", in Paul Buhle (ed.), C.L.R. James: His Work and Life (London, I986), pp. I85-194.

16. "Documents from the Discussions with Leon Trotsky", in Scott Mclemee (ed.), C.L.R. James on the "Negro Question" (Jackson, MS, I996), pp. 3-16, 4.

17. "Historical Development of the Negroes in American Society", in Mclemee, C.L.R. James, p. 8, pp. 63-89; Worcester, C.L.R. James. 
By the mid-I940s the Trotskyites had reluctantly come to accept James's position that an "independent Negro struggle" would be desirable without white leadership, whether in the party or in the unions. ${ }^{18}$

In the I950s, James' splinter group, itself an interracial cohort, further elaborated on the African-American predicament within the car factories. The most important document in this respect was Charles Denby's Indignant Heart: A Black Worker's Journal (1952). ${ }^{19}$ Cast in the form of an autobiography, Indignant Heart presented the story of a black Southern migrant who had moved to Detroit to work in the car factories. The narrative, rich in evocative and self-contained anecdotes, touched upon all the issues advanced by the "Johnsonites" (as they were sometimes called): the efforts of trade unions to restrict the spontaneous militancy of the working class; workers' disaffection with a union bureaucracy that stifled democratic participation; workers' ability to organize production on the shopfloor without supervision ("We ran the job just as we wanted to", testified Denby in one instance); ${ }^{20}$ and the hypocrisy of both liberal unions and leftist parties in matters of racial equality. The book took a particularly strong stand in support of both the possibility of interracial co-operation among workers and the necessity of an autonomous black struggle. It sharply criticized the idea - much favoured even by the Trotskyites, some of whose positions the book sought to challenge - that "Negroes will have to forget they are Negroes and be Marxists". Until the Black Maoist groups of the I970s, Correspondence was the only organization that tried to integrate fully the independent black struggle into the tradition of Marxism.

In 1953, C.L.R. James - an undesirable alien radical according to the FBI - was deported from the United States and settled in the UK, from where he continued to offer guidance to the Detroit comrades. James's banishment from the United States left the group without its most inspiring leader. In 1955, Dunayevskaya, who resented the subordinate status that she felt James had assigned to her, left Correspondence with a small cohort to form "News and Letters". ${ }^{21}$ Never a large group (even though able to disseminate its ideas to a large audience), the "Johnsonites" suffered another split in 1962, which further reduced their membership and eventually drove them to dissolution. In I96I, James Boggs, longtime autoworker and editor of the magazine Correspondence, drafted an internal "paper of evaluation" in which he concluded that the next revolutionary phase in the United States would see as protagonists not

I8. Mclemee, C.L.R. James, p. xxiv.

19. Charles Denby, Indignant Heart: A Black Worker's Journal (Boston, MA, 1952).

20. Ibid., p. I 28.

21. Martin Glaberman to Bruno Cartosio, 20 January 1975, Archives of Labor and Urban Affairs (ALUA), Martin and Jessie Glaberman Collection, box 39, folder 24. 
workers, but the "outsiders", above all, African Americans. This paper was later published in book form with the title The American Revolution: Pages from a Negro Worker's Notebook. ${ }^{22}$

The paper was written in the context of the sit-ins that were staged in the South to promote the cause of desegregating public facilities, and the resurgence of black nationalist tendencies in Detroit, in particular within African-American churches. From London, C.L.R. James denounced the position as a rejection of the working class as a viable revolutionary force and urged the group to organize education classes in Marxism. James and Grace Lee Boggs felt this to be a patronising response from an intellectual imbued with theory and books, but out of touch with the changes that were taking place in America. Together with a few other members, they left Correspondence but retained control of the publication. The twenty-five or so remaining members, of whom about one-half were in Detroit, started calling themselves "Facing Reality". Under the leadership of Glaberman, the most prominent and experienced militant among those who remained politically close to James, they continued political activity. As the struggle in Detroit's factories and neighbourhoods radicalized in the late i960s, Glaberman realised that the group was neither able to influence political action in any significant sense nor to recruit new members, even though it was a time of intense working-class mobilization. In 1970, "despite increasing interest in our ideas and our publications", he thought that the organization had "outlived its usefulness", and moved to dissolve it, against James's advice. ${ }^{23}$

The importance of the Johnson-Forest Tendency, a group that never comprised more than roo members, lies in the theory that it developed and the method of activism that it espoused. Theoretically, the Johnsonites were among the first groups to advocate the autonomy of the working class from its "natural" organizations, the trades unions and the Communist Party. They emphasized the historical and contemporary ability of workers to break in unexpected ways from those who tried to bridle them. In "Notes on the Dialectic", James argued that the workers' "new organism will begin with spontaneity, i.e. free creative activity, as its necessity". ${ }^{24}$ From their base in Detroit, the Johnsonites also engaged in a different method of active intervention in the workers' struggle. In the early i950s, James had organized in New York a "Third Layer School", where, rather than meekly listening to intellectuals, rank-and-file workers would tell them about their life in the factories. Their belief in self-organization led the Johnsonites to research the actual condition of the working class, setting aside the

22. James Boggs, The American Revolution: Pages From a Negro Worker's Notebook (New York, 1973).

23. Martin Glaberman to Bruno Cartosio, 20 December 1974, ALUA, Martin and Jessie Glaberman Collection, box 39, folder 24; Lee Boggs, Living for Change, p. 100.

24. C.L.R. James, "Notes on Dialectic", Radical America, 4 (1974), p. 4. 
entrenched representations of unionists and communists. As we will see, the theoretical and political work of the Johnson-Forest Tendency served as an inspiration to other groups in Europe, and was a precious legacy to the new generation of revolutionary activists who made headlines in Detroit in the late i960s.

\section{Atlantic crossings}

A similar dissatisfaction with union bureaucracy, the role of the communist parties and the development of the Soviet Union, featured in the analysis carried out by a small number of labour activists in Europe, in particular in France and Italy, but also in Great Britain and the Netherlands, where the Americans were in contact with critics of Trotskyism such as Tony Cliff (in the UK) and the septuagenarian Dutch Council communist, Anton Pannekoek. ${ }^{25}$ In 1949 in Paris, two former Trotskyites, Cornelius Castoriadis (who sometimes used the name Pierre Chaulieu) and Claude Lefort, founded Socialisme on Barbarie, the name both of a group and of a journal which argued for the importance of the workers' struggle at the point of production, unhindered by official unions or party organizations. ${ }^{26}$ Working in parallel with the Americans, the French group had developed arguments similar to those debated by James and others in Correspondence. Very soon they started a close political and personal relationship. For six months in 1948 Grace Lee Boggs resided in Paris and established a "daily collaboration" with the members of the group, which "allowed them to enrich and develop their ideas". ${ }^{27}$

In the same period Socialisme ou Barbarie ran a translation in eight instalments of Romano's American Worker, hailed as proof that workers could resist the traps of alienation, consumerism, and union bureaucracy, and wield power on the shopfloor. Romano's pamphlet inspired a member of Socialisme ou Barbarie, Daniel Mothé, to write an account of the workers' struggle at Renault from a similar perspective. The book criticized the unions' tendency to integrate with capitalist society and the factory without challenging the dominant mode of production. According to Mothé, the causes of the unions' tendency towards accommodation lay in the lack of internal democracy, and the division between the leadership and rank-and-file members. In Mothés judgement, however, the workers were well able to organize autonomously, whether inside or outside the union.

25. Philippe Gottraux, Socialisme ou Barbarie. Un engagement politique et intellectuel dans la France de l'après-guerre (Lausanne, I997), pp. 24I-242; Marcel van der Linden, "Socialisme ou Barbarie: A French Revolutionary Group (1949-65)”, Left History, I (1997, recte 1998), pp. 7-37.

26. The most comprehensive study of this group is Gottraux, Socialisme on Barbarie.

27. Castoriadis quoted in Gottraux, Socialisme on Barbarie, 243. 
The strike committees at Renault were a case in point: a form of direct, participatory industrial democracy, which achieved goals that the unions had always postponed. Castoriadis reiterated this point when he said that "the revolutionary organisation could not be a 'director' of the working class but, rather, an instrument - one of the instruments - of the revolutionary struggle". In other words, nothing should constrain the autonomous drive of the working class. ${ }^{28}$

In the early I950s Italy this analysis appealed to those left-wing activists who questioned whether the dogmatic Marxist narrative propounded by the Italian Communist Party really applied to the actual conditions of the Italian working class. In the mid-I950s the ideas of the Johnson-Forest Tendency began to filter through to dissident Marxist circles in Italy as a result of the translation by Danilo Montaldi of Romano's and Mothés work. Montaldi was an essayist and sociologist who had left the PCI after the war. In his preface to the translation of The American Worker, Montaldi acclaimed it as a sign that, contrary to the prevalent assumption, the American working class remained class-conscious and had not fallen for the ideological blandishments of capitalism. In his native Cremona, Montaldi founded in 1957 a group called Unità Proletaria, that distanced itself from the Communist Party and established direct contact with Socialisme ou Barbarie, Correspondence, News and Letters, and European groups that espoused the same line: the British Solidarity for Workers' Power, the Belgian Pouvoir Ouvrier, the Dutch Spartakus and others. Montaldi described Correspondence in flattering terms as the American "revolutionary vanguard", a group that understood that,

$[\ldots]$ the worker is first of all someone who lives at the point of production of the capitalist factory before being the member of a party, a revolutionary militant or the subject of coming socialist power. It is the productive process that shapes his rejection of exploitation and his capacity to build a superior type of society, $[\ldots]$ and his class solidarity.

The development of this fundamental idea, wrote Montaldi, was Correspondence's crucial contribution to the contemporary revolutionary movement. ${ }^{29}$

\section{Quaderni Rossi and autonomist Marxism in Turin}

Montaldi's account constituted a challenge to the PCI's (the Italian Communist Party) analysis of the Italian situation. To the communists,

28. "The Only Way to Find Out if You Can Swim Is to Get into the Water": An Introductory Interview (1974), in Cornelius Castoriadis (ed.), The Castoriadis Reader (Oxford, 1997), p. 7; Daniel Mothé, Militant Chez Renault (Paris, 1965).

29. Preface to "L’Operaio Americano", in Danilo Montaldi (ed.), Bisogna sognare. Scritti 1952-1975 (Milan, I994), pp. 500-518, 501. 
Italian capitalism was backward and rested on the predominance of decaying monopolistic concentrations, destined - the party claimed - to be absorbed by the state when they failed. They therefore emphasized the importance of seizing control of the political levers in Rome and abandoned the notion of initiating the struggle at the point of production. Italian communists did not even deem it necessary to use the social sciences to study workers. "Bourgeois" science, they claimed, was not suited to investigating the "objective" conditions of the working class, on which only the Marxist tradition, as interpreted by the Communist Party, could shed any light.

Soon, however, local groups of dissident communists and socialists came forward to propose an alternative analysis. The best known was the group that gathered around the review Quaderni Rossi, directed by Raniero Panzieri. Edited and published in Turin, Quaderni Rossi was also particularly interested in autoworkers, and cultivated an interpretation of Marxist theory more geared to understanding its actual impact on workers caught in an ever-changing production process, as opposed to focusing, as leftist parties and unions often did, on its philosophical and historical meaning. Quaderni Rossi explored in depth the question of workers' autonomy vis-à-vis the party; the group came to propound the thesis that the working class was not the passive victim of changes in capitalism, but had the power to initiate struggle and to force change on the capitalist structure. This contention underpinned the so-called operaismo (workerism) of the Italian radical left in the $1960 .^{30}$

This stance reflected that of the Detroit radicals, but was sustained by a subtler theoretical analysis. Panzieri, for instance, "re-read" several passages of Capital in a way that was at variance with that of the traditional left. In "The Capitalist Use of Machinery of Neocapitalism", Panzieri criticized the received wisdom of the left that technology was an objective variable that could be turned to the advantage of the working class - that is, if the working class gained control of it politically. As James and Dunayevskaya had shown in the case of the Soviet Union, the control exercised by the socialist state was not always preferable. Panzieri added force to this critique by characterizing simple faith in technology as misguided, and a revival of the romantic idea that machines would liberate men from work. He argued that technological development could only serve the purpose of the productive process that had generated it: the capitalist productive process. ${ }^{3 \mathrm{I}}$

30. The best treatment of Italian workerism in English is Steve Wright, Storming Heaven: Class Composition and Struggle in Italian Autonomist Marxism (London, 2002). In Italian see Guido Borio, Francesca Pozzi, Roggero Gigi, Futuro Anteriore (Rome, 2002) and, recently, Giuseppe Trotta and Fabio Milana (eds), L'operaismo degli anni sessanta, da "Quaderni rossi" a Classe operaia (Rome, 2009).

3I. Raniero Panzieri, “The Capitalist Use of Machinery, Marx versus the 'Objectivists'”, now collected in Phil Slater (ed.), Outlines of a Critique of Technology (London, 1980), pp. 44-68. 
Panzieri filled the editorial board with young intellectuals and activists such as Romano Alquati, Liliana and Dario Lanzardo, Vittorio Rieser, Giovanni Mottura, Emilio Soave, and Goffredo Fofi, among others. On the basis of individual or collective projects of investigation into the working-class condition, Quaderni Rossi described the emergence of a new (for Italy) industrial protagonist: the "mass-worker" in the increasingly automated factory. Where the Old Left had assumed that Italian capitalism was intrinsically backward, Panzieri and the others saw the existence of such mass-workers as proof of a dynamic development compatible with the American Fordist model.

These conclusions were heavily influenced by the research conducted upon the FIAT workforce - increasingly unskilled, of southern origins, and indifferent to the politics of the Old Left. In 1961, Romano Alquati pioneered a new kind of workers' research at FIAT. ${ }^{32}$ In many respects, the method and the analysis were reminiscent of Romano's American Worker, but Alquati had earlier perfected the method of conricerca - a "joint research" between intellectuals and workers - as a member of the Gruppo d'Unità Proletaria founded by Montaldi. ${ }^{33}$ Two themes ran through Alquati's report, later published by Quaderni Rossi: first, the pre-eminence of a new working class at FIAT, disillusioned with the company, but indifferent also to left-wing unions and parties. Alquati controversially argued that even a large company such as FIAT failed to "integrate" workers into capitalism and to neutralize their rebelliousness: whatever beliefs these youngsters had held before entering the factory about the desirability of industrial work, they were quickly shed after only a few months' work at the point of production. Relatively high wages (for some) and, therefore, consumerism did not lessen the effects of alienation.

Any resurgence of class struggle within the firm would be based upon these forze nuove, as Alquati called them. Even though the "new forces" lacked class-consciousness in a traditional sense, they spontaneously understood the need for "self-determination", that is, self-organization of the factory. ${ }^{34}$ Secondly, Alquati emphasized the inability of the traditional left to identify and make use of these new trends. The report accused the unions and the PCI leadership of focusing on loftier political goals, such as reform laws, that did not directly affect factory conditions. The politics

32. Romano Alquati, "Relazione sulle 'forze nuove'. Convegno del PSI sulla FIAT, gennaio 1961", and idem, "Documenti sulla lotta di classe alla FIAT", in idem, Sulla Fiat e altri scritti, (Milan, 1975), pp. 314-34I.

33. Sergio Bologna, "Der Operaismus, eine Innenansicht: von der Massenarbeit zur selbständigen Arbeit", in Marcel van der Linden and Karl Heinz Roth (eds), Über Marx hinaus Arbeitsgeschichte und Arbeitsbegriff in der Konfrontation mit den globalen Arbeitsverbältnissen des 2I. Jahrbunderts (Berlin, 2009), pp. I55-181, I6I.

34. Alquati, "Relazione sulle 'Forze nuove", p. 35. 
of the traditional left did not measure up to the politics of the new working class or, conversely, the new workers did not perceive their action to be "political" because they associated politics with parliamentary politics in Rome. The union's bureaucratic structure "isolated the headquarters from the reality" on the shopfloor. Union delegates in the factory, wrote Alquati, were stranded midway between the distant and abstract politics of the union and the actual potential for workers' collective resistance. However, they were unable to bridge the gap between these two worlds and lead the struggle. The solution lay in a new "organizational praxis" through which the new workers would be led to analyse their situation. ${ }^{35}$ Alquati did not question directly the need for a union, but what he left unsaid was that the new situation required a thorough overhaul of the traditional organizations or the creation of new ones.

\section{From Quaderni Rossi to Classe Operaia}

At this stage, the other major contribution to workerism came from Mario Tronti, the second prominent theorist to write for Quaderni Rossi. In Workers and Capital, a book published in 1966 that collected his writings of the previous five years, Tronti elaborated upon the insight that capitalist development follows, and does not precede, workers' insurgency, which itself echoed C.L.R. James's point that "The proletariat always breaks up the old organization by impulse, [and makes] a leap." ${ }^{6}$ Workers were not passive victims of capitalist change, indeed quite the reverse. The political party, argued Tronti, must not conduct the revolution outside the factory, in the realm of politics: the real political action occurs at the point of production. The dissolution of capitalist society and of the bourgeois state can only occur from within the productive process. ${ }^{37}$ Tronti eloquently made the case for the historical and political significance of "autonomist" political processes. The factory was to be the centre of social protest. The centrality of industrial workers was the outcome of the ever increasing propensity of capitalism to control the human factor in production, which gave it a centrality that only increased its power of disruption.

As a result, Tronti was at odds both with those (the Old Left) who looked to the Soviet Union as a revolutionary model and those (within the New Left) who believed that the epicentre of change would have to be the less developed Third World countries. Only industrial workers, wrote

35. Idem, "Documenti sulla lotta di classe alla FIAT", p. 63.

36. Cleaver, Reading "Capital" Politically, p. 67. For further information about C.L.R. James's connection to Italian autonomism see Christian Hogsbjerg, “A 'Bohemian Freelancer'? C.L.R. James, His Early Relationship to Anarchism and the Intellectual Origins of Autonomism", paper presented to the conference "Is Black and Red Dead?", University of Nottingham, 2009. 37. Mario Tronti, Operai e capitale (Turin, 1966), p. 59. 
Tronti, had the potential to tear down the capitalist "plan". Tronti did not endorse full spontaneity - an idea that later gained ground among "autonomist" Marxists - and recognised instead that the party had a crucial tactical role in channelling workers' self-determination: "The working class has a spontaneous strategy of its own motions and development: the party needs only to detect it, express it, and organize it." ${ }^{8}$ The refusal to abandon the PCI as an instrument for revolution was an important difference between Tronti and the Correspondence group, and it showed how national peculiarities (the presence of an established communist party) could impart a different shape to an analysis that otherwise shared the same premises. However, Tronti never tired of emphasizing that the Communist Party could give the lead to revolutionaries only by having the factory as its focal point. The struggle, wrote Tronti, must not concern the upper echelons of the bourgeois state, but be located in the production process on the shopfloor, or, in Tronti's inflammatory style, "the workings of the bourgeois state must be shattered today within the capitalist factory". ${ }^{39}$

Like the autonomist Marxists in Detroit, the Quaderni Rossi group split because of personal and tactical, as well as theoretical, differences. Should the group directly sustain the working-class struggle itself, even outside the traditional form of union-supported strikes? Or should it remain a predominantly theoretical publication, giving ample space to "workers' enquiries", and providing theoretical tools for a new kind of revolutionary leadership? Tronti (from Rome) supported the first position; Panzieri (from Turin) the second. Eventually Tronti and his followers founded a new journal, Classe Operaia, which further developed the workerist themes present in Quaderni Rossi. The latter lasted until I965, but lost much of its political influence after the death of Panzieri in I964.

Classe Operaia, whose first issue appeared in February 1964, sought to play an important role in the upcoming workers' struggles; its editors wanted to "intervene" in them. Ironically enough, it would chiefly serve to inspire a new generation of radical leaders (what Quaderni Rossi had hoped to do) rather than actually play a political role. In Turin, the political impact of the group upon the actual factories was negligible (it was different elsewhere), but in its brief life the journal elaborated on the central workerist tenet that deeply influenced the Italian radicalism of the late I960s: the central place of the working class as a driving force of capitalism. ${ }^{40}$ "Capitalist development", wrote Tronti in the first issue of the journal, "is subordinated to the workers' struggle; it comes afterwards,

40. Wright, Storming Heaven, p. 63. 
and [capitalism] must shape the political workings of its production accordingly". ${ }^{\mathrm{I}}$

The relation of the working class to the traditional left, and in primis to the PCI, was, throughout the short life of the group, a cause of tensions and divisions. Notwithstanding his criticisms, Tronti remained a member of the Communist Party and hoped to move its mainstream towards his position and away from a social democratic approach. He did not wish to create a new party to the left of the communists. Workerists, he argued, could be more effective as a fifth column inside the Communist Party, not outside (interestingly, the same consideration in the I940s had persuaded, for a while, the Johnson-Forest Tendency to remain within the Socialist Workers' Party). Tronti believed that only a deeply rooted organization such as the PCI stood any chance of leading a revolution, even if that required a profound change in its politics. However, most young people who had joined the group, whether in Rome, Padua, Florence, or Turin Toni Negri, Pierluigi Gasparotto, Claudio Greppi, Franco Piperno, Francesco Tolin, and many others - were of a different mind. For Negri, the leader of the dissidents, the PCI was an enemy, a behemoth organization out of touch with what was happening in the factories. For many workerists the relationship with the PCI was still ambiguous for much of the I960s, and the question of a break with it controversial. Yet the party was accused of merely "institutionalizing" workers' insurgency. ${ }^{42}$

By 1967 Classe Operaia had imploded. It split into several workerist groups functioning as distinct local organizations, and soon adopted the name of Potere Operaio. However, there was something ironical about the dissolution of Classe Operaia, namely the fact that it occurred on the eve of the greatest workers' mobilization in Italian history. Workerists missed the last opportunity to present themselves as a unified, even if not wholly coherent, group. The onset of the insurgency shifted the interest of the members to the way theory could be applied in action, and to how new events might shape theoretical analysis. There resulted an accumulation of diverse positions, tactics, and goals in constant flux, and interaction with the spontaneous strikes occurring in the factories.

\section{RADICALISM AND REVOLT IN THE MOTOR CITIES}

Detroit and Turin radicals were similar not only in the ideas that they espoused, but also in the practice of combining intellectual reflection with political intervention. The most committed members of these groups saw themselves as a militant avant-garde, which acted in a specific social space

4I. Tronti, "Lenin in Inghilterra", in idem, Operai e Capitale, pp. 89-95, 89. 42. See the interviews in Trotta and Milana, L'operaismo degli anni sessanta. 


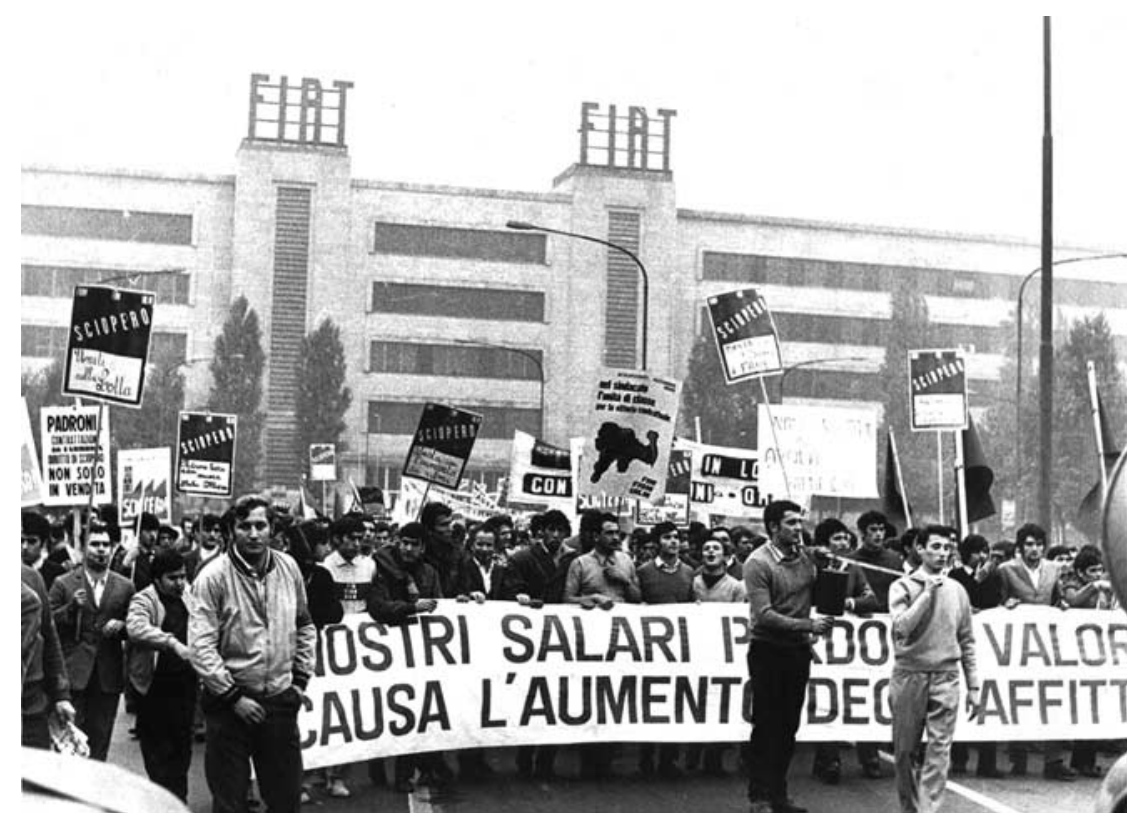

Figure 2. Car workers striking in front of FIAT’s Mirafiori plant during the "Hot Autumn", a period of escalating workers' unrest. The photo conveys the boastful enthusiasm of the participants, very often young workers and southern immigrants.

Source: http://libcom.org/history/organising-fiat-1969.

and measured its impact in terms of the actual transformation of the relations of production, rather than the theoretical value of their statements. Raya Dunayevskaya recapitulated this attitude when she wrote that "there is a movement from practice to theory that is literally begging for a movement from theory to practice to meet it". ${ }^{43}$ The intended audience for newsletters and pamphlets - their main tangible output - was composed of workers and activists in the labour movement, rather than of members of an intellectual milieu. The distinction between intellectual practices and political practices is slippery (as the former may have a political content and the latter a theoretical significance), ${ }^{44}$ but it is nevertheless important to draw, in light of the fact that a great part of the historical evidence pertaining to those groups casts them, retrospectively, more in the role of intellectuals than of political activists.

A further similarity concerns the reasons why American and Italian radicals, whose activity was anchored in the local industrial context,

43. "Communism, Marxism, and Liberty - The American Humanist Tradition", ALUA, Raya Dunayevskaya Collection, microfilm no. I25 I4.

44. A point made by Gottraux, Socialisme on Barbarie, pp. 9-10. 
looked beyond the nation for inspiration and network-building. In part, this flowed from the international purview of their conception of political change, which characterized capitalism as a global phenomenon. However, the transnationalism also stemmed from the numerical marginality of these groups within their own national territories, which spurred the activation of alliances with militants elsewhere. It was, wrote retrospectively postworkerist theorist Christian Marazzi, a way to avoid a "ghettoization" which neutralized the importance of workers' autonomist history. ${ }^{45}$ The repeated travels of some of these radicals and the frequent reciprocal references in their publications also suggest that many of their ideas, practices, and tactics were hatched in the transnational arena. However, there was never a "general line" to which these groups subscribed. Differences coexisted within the encompassing language of an "autonomy" of the working class from the traps of institutionalization and doctrinarianism.

Another fertile ground for comparative analysis lies in the way that industrial relations broke down in the automobile factories and social protest flared up in Detroit and Turin from 1968 onwards. In both cases, a massive wave of immigration had recomposed the working class and drastically changed the demographics of the cities. In Detroit, African Americans had moved in during the I940s and I950s (and even afterwards) as a part of a wider migration from the American South. A negligible percentage of the industrial workforce before the war, they gained a foothold in the automobile industry during the labour shortage that accompanied the conflict, overcoming the resistance of employers and fellow white workers. As many factories and their workers relocated beyond city limits in the postwar years, blacks were left behind in the remaining, ageing plants. They constituted about 30 per cent of the Detroit-area automobile plant's workers in 1960, but in the production departments swelled into a majority by $1968 .{ }^{46}$ In Turin in I 960 only I 5 per cent of car workers were southern Italians; by 1972 this had multiplied to 40 per cent, also concentrated in production departments. ${ }^{47} \mathrm{In}$ fact, on both sides of the Atlantic the workings of the labour market had changed in the late I960s, when companies reluctantly hired African Americans and southern migrants for the core production jobs that had previously been the preserve of established residents - "whites" in Detroit or Piedmontese natives in Turin. In this way the auto industry's decisions fuelled rapid demographic change and urban transformation.

Tensions over competition for housing and resources between newcomers and natives were compounded by ethnic (and in Detroit, racial) prejudices. Racial discrimination took a heavier toll on African Americans, since they

45. Sylvere Lotringer and Christian Marazzi, “The Return of Politics", in idem (eds), Autonomia: Post Political Politics (London, 2007), pp. 8-21, I 2.

46. Sugrue, The Origins of the Urban Crisis, p. 97.

47. Musso, "Il lungo miracolo economico", p. 92. 
were victims of a racially segmented labour and housing market, of police brutality, and of none too subtle forms of social segregation..$^{8}$ Nevertheless, in Turin, Italian southern immigrants too encountered housing discrimination and were concentrated in run-down sections of the city centre or in building projects in degraded suburbs poorly connected to the rest of the metropolitan area. Even though their problems were not exacerbated by "race", southern immigrants were at the mercy of a dual labour market that throughout the I950s and most of the I960s allotted high-paid, steady jobs to natives, and precarious low-wage occupations to newcomers.

A comparison between Detroit and Turin helps to put into sharper focus the distinctive impact of "race" on autoworkers' lives and on the radicalization of some of them. Racial discrimination is usually deemed crucial in Detroit, where African Americans rebelled at the cusp of the civil rights movement, but in Turin, despite the absence of racial grievances, protesting workers to some extent framed a similar political agenda and shared analogous tactics. Racial discrimination was an inescapable issue in postwar Detroit; yet it was significant not as an allencompassing explanation of social conflict, but in the way it interplayed with class dynamics and structural change common to other places.

The spontaneous discontent breeding in the factories and in the working-class neighbourhoods of Detroit and Turin in the late r960s was captured by some radical groups that had incorporated into their programmes many of the insights gleaned in the previous fifteen years by the Johnson-Forest Tendency, Correspondence, Quaderni Rossi, and Classe Operaia - groups that could engage in a dialogue because, notwithstanding local differences, they located themselves in a similar position within a global opposition to capitalism. The Dodge Revolutionary Union Movement (DRUM, later the League of Revolutionary Black Workers) in Detroit and Lotta Continua and Potere Operaio (a smaller organization) in Turin represented a - sometimes uneasy synthesis of this older tradition of radicalism with the activism of New Left students.

In some respects these radical groups spoke different political languages. Even though the leaders of the League described themselves as Marxist-Leninists, their ideology included elements of black nationalism as indicated by their racially virulent language. This led members of the League to establish extensive contacts with competing revolutionary organizations, such as the Republic of New Africa and the Black Panthers, which stood for Black Power. Lotta Continua and Potere Operaio, on the other hand, explicitly rejected the Leninist idea of a vanguard party meant to capture the lead of the working class, and propounded that the latter 
produced its own internal vanguard ${ }^{49}$ In both cases, however, ideological dogmas were secondary to the pragmatic issues of factory and community organizing for revolutionary change. The fact that these groups emerged and were consolidated in two cities shaped by similar social phenomena set their agenda in a comparable way.

For instance, even though DRUM's demands were explicitly provocative and racially subversive ("enough to turn a sociologist into a pathologist", wrote an unsympathetic commentator), ${ }^{50}$ including as they did, the request for an African American at the head of Chrysler's Board of Directors and a black President of the UAW, observers were mistaken in the assumption that the black workers' agitation could be framed exclusively in terms of "race". DRUM differed from contemporary blackpower-style groups, inasmuch as it aimed to organize African Americans as workers, exploiting their leverage at the point of production. Their "fourteen demands" reflected less a black nationalist agenda, than the legacy of Detroit's tradition of autonomist Marxism - a tradition that, as we have seen, had much in common with the theoretical speculations of the Italian workerists. Their demands included the request to work fewer hours, in a safer environment, and at higher rates of pay, a rejection of the constraining union grievances procedure ("which prevents workers from using their strike power to fight abuses") and the refusal of union dues and the union's bureaucracy in general. ${ }^{\mathrm{I}}$

These demands all reflected the political education that the leaders of DRUM - General Baker, John Watson, Mike Hamlin, and Chuck Wooten, among others - had received in the radical groups of the early ig6os. DRUM's leading members came of age just as communists, Trotskyists, and their splinter groups were tentatively rebuilding their organizations after McCarthyism and were actively looking for proselytes. Of these organizations the most influential were Correspondence and Facing Reality, where Martin Glaberman, James Boggs, and Grace Lee Boggs acted as charismatic mentors and made a strong impression on the rising generation..$^{52}$

The parallels with the situation unfolding in Turin were as striking to contemporaries as they are to the historian now. In the Italian motor city, Lotta Continua (the organization with the largest following) and Potere Operaio had also refined their political lines by adapting the basic principles of the workerist tradition to the mounting unrest in the automobile plants. As in Detroit, the younger leaders, such as Adriano Sofri, Luigi Bobbio,

49. See here the discussion on organization internal to Tuscany's Potere Operaio and the position of Adriano Sofri quoted in Luigi Bobbio, Storia di Lotta Continua (Milan, 1988), pp. 30-37.

50. Victor Riesel, "Inside Labor: Black Drums", press report, I4 August 1968, ALUA, Art Hughes collection, box 47, folder I.

51. "Drum's Program", Inner City Voice, 2:3 (1970).

52. Dan Georgakas, "Young Detroit Radicals", in Buhle, C.L.R. James, pp. I85-194. 


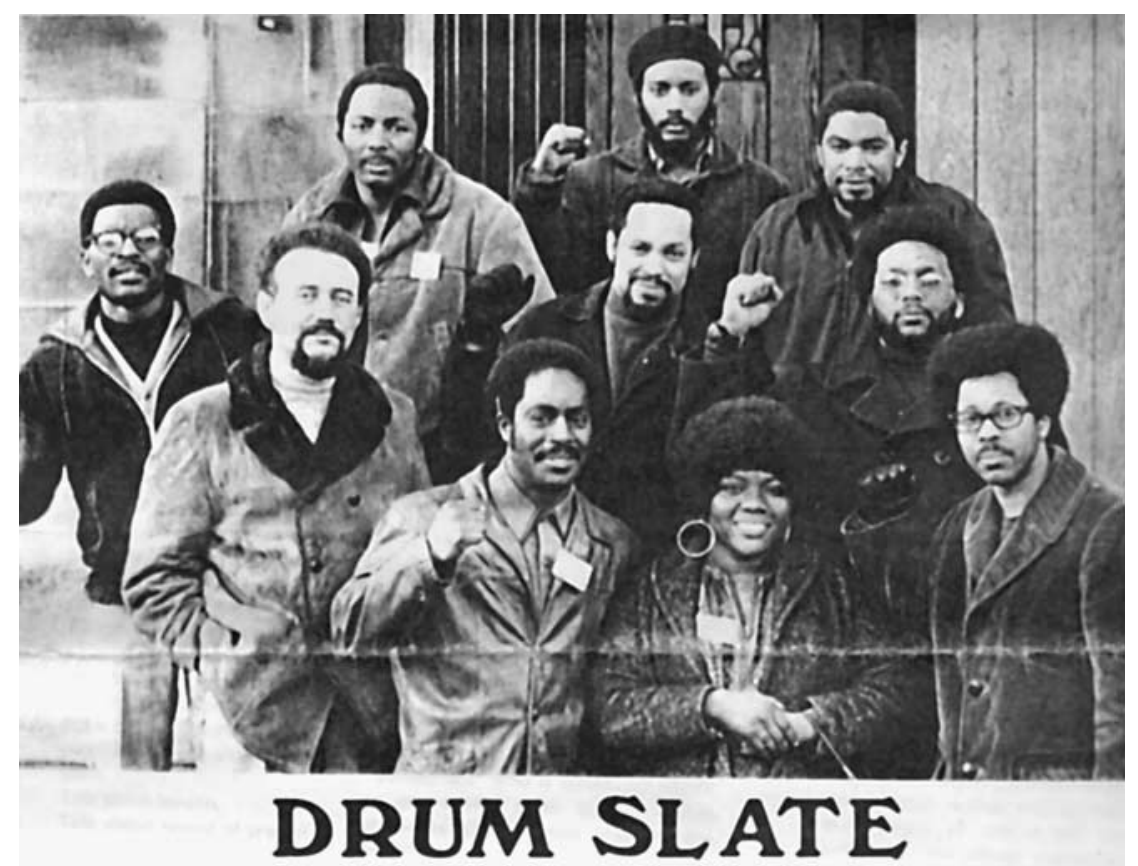

Figure 3. The DRUM candidates for the Detroit UAW Local 3 election in 1970 pose for a collective picture. As the raised fists and Afro hairstyles suggest, the group propounded a Marxist-Leninist ideology tinged with black nationalism.

Source: Inner City Voice.

Mario Dalmaviva, Franco Piperno, Emilio Vesce, and Sergio Bologna (who were either based in or travelling to Turin in that period), had honed their political skills through personal acquaintance or by reading thinkers such as Renato Panzieri and Mario Tronti. Other participants in the Turinese movement came from the ranks of the student movement.

In the spring and summer of 1969, Lotta Continua, whose core leadership initially consisted only of students, reached out to the production workers in FIAT factories (mostly southern immigrants) by advocating "liberation" from union control. They claimed that unions were "official" institutions which could no longer genuinely represent the workers. They held that the union-negotiated contract could not or should not become a "cage" imprisoning the insurrectionary impulses of the workers. Further, more explicitly than in Detroit, Turinese radicals demanded "less work and more money" (a slogan initially issued by Potere Operaio). ${ }^{53}$ For Lotta Continua the request for higher wages was meant to sever the nexus 
between remuneration and productivity that characterized the Fordist model - the best way to cripple the system. In both cases the high level of unauthorized industrial conflict - often in the shape of innovative protest actions, such as demonstrating within the plants and partial and temporary stoppages on the line - seemed to confirm the radicals' key insight of a growing gap between the institutions of the traditional left and the workers; workers, they claimed, were organizing themselves and bypassing the checks and restraints of the procedural union rules.

It was in this context that the intellectual and personal contacts between Detroit and Turin radicals dating back to the late i950s were rekindled by the almost simultaneous workers' struggles in the car factories. Italian militants avidly followed the development of black workers' struggles in the United States. Ferruccio Gambino, a young activist close to Classe Operaia, and later a member of Potere Operaio, joined the Facing Reality group when he visited Detroit for a few weeks in 1967. On that occasion, Gambino initiated a long-standing friendship with Martin Glaberman. The two established a sort of bridge between Detroit and a host of Italian cities, thus enabling political activists on both sides of the Atlantic to travel, exchange literature, and discuss the analogies and differences between their own national settings. ${ }^{54}$ In the same year, George Rawick was Gambino's guest in Padua where the latter was a junior member of the Institute of Political and Social Sciences. Rawick - a long-time associate of James and Glaberman, a radical historian and the author of From Sundown to Sunup: The Making of the Black Community, a pioneering study of the slave's experience - lectured in Milan and Trento as well as Padua (though not in Turin) on the African-American struggle. In I968, James Boggs, the charismatic black radical who had broken with C.L.R. James, toured Italian universities during the campus occupations, talking to students about Black Power and the revolutionary groups in Detroit. 55

Two other radical intellectuals played a crucial role in establishing links between Italian and American radicals. One was Roberto Giammanco, a professor of philosophy at Wayne State University, who had long since left his native Pisa but who had not severed all contact with the left-wing academic world in Italy. Giammanco had published the earliest booklength analysis of Black Power available in Italian and was the first to translate into Italian the Autobiography of Malcolm X, whom he knew personally. ${ }^{56}$ It was Giammanco who facilitated Boggs's lecture tour

54. Lee Boggs, Living for a Change, p. I49. Interview with Ferruccio Gambino as quoted in Borio, Futuro Anteriore (in the included CD-Rom).

55. Ibid., p. I 40.

56. Roberto Giammanco, Black Power: potere negro (Bari, 1967); and Autobiografia di Malcolm $X$ (Turin, 1967). He would later translate Carmichael's and Hamilton's Black Power. 
in 1968 and arranged for the translation and publication in Italy of his The American Revolution. Although not much is known about him, Giammanco emerged as a crucial node in the circulation of ideas and people between Detroit and Italy. ${ }^{57}$

The other key figure was Dan Georgakas, an intellectual and militant of Greek origin who had lived all his life in Detroit and who closely observed the parallel developments in Detroit and Turin. Georgakas had studied with Giammanco at Wayne State University and first travelled to Italy in I964 on a social science exchange programme. ${ }^{5}$ During the following ten years, Georgakas travelled back and forth between Detroit and Italy, writing in Italian New Left journals about the movement in the United States and in American radical magazines about the Italian workers' protests. He later co-wrote the first full-length historical treatment of the League of Revolutionary Black Workers. Georgakas facilitated the first trip of John Watson to Italy in December 1968, when the leader of the League addressed a conference on the theme of imperialism. When Watson visited Turin the student movement was at its peak, and several departments of the local university had seen drawn-out occupations. The Italians wanted to know about Black Power and the automobile workers' strikes in Detroit; Watson in turn learnt about the new Italian radicalism. His trip thus served to perpetuate and extend the circulation of ideas, tactics, and projects that had characterized the exchanges between Italian and American radicals since the late i950s. At this point, after the riot of July 1967 and the DRUM-led strikes of 1968, workers' radicalism was more widespread in Detroit than in Turin. "Watson - according to Georgakas - was amazed at what he considered the tactical and ideological timidity of the Italian Marxists, especially given their enormous working-class base" ${ }^{59}$ However, the situation soon reversed itself.

\section{Parallel developments}

It is difficult to assess the degree to which these reciprocal contacts were influencing the evolving movements in Turin and Detroit; they nevertheless attest that its protagonists were fully alert to the international dimension of local struggles - something that is generally neglected by historians. This awareness further increased when industrial conflict intensified in Turin's FIAT factories from the spring of I969. By October 1969, occasional strikes at FIAT's flagship plant, Mirafiori, had developed into almost daily agitations. The departments most affected were the core production units of bodywork, chassis, and paint, where southern

57. Interview with Dan Georgakas, April 2002, in the possession of the author.

58. E-mail interview with Dan Georgakas, June 2008, in the possession of the author.

59. Dan Georgakas and Marvin Surkin, Detroit: I Do Mind Dying (Boston, MA, 1998), p. 50. 
immigrants comprised the overwhelming majority of the workforce. Often, spontaneous marches within the plant led to violent confrontations with the firm's private police as protesters passed through the shops inviting other workers to join.

In 1970, in the wake of the "Hot Autumn", John Watson, on his second trip to Italy, toured several cities including Turin, to promote his selfproduced documentary about the League, the film Finally Got the Neres. Detroit radicals were impressed both by the intensity of the struggle and its resilience, but criticized the Italians for not daring to use this strength to organize an armed struggle. It seemed to Watson that Italians talked about an armed revolution as something to happen in a distant, remote future; the American situation had instead taught black workers that such a scenario was imminent. Of course, ironically, it would be in Italy that radical groups embraced armed struggle, while the League's plans for violent actions, if they existed, never came to fruition. Another difference emerged in the way black revolutionary workers self-adopted the label "Marxist-Leninist". Italian workerists were wary of any reference to a vanguard party that would lead the proletariat. In fact, this stance contradicted the call for workers' selforganization. It pointed out a theoretical inconsistency in the approach of the Americans. Watson avoided controversy by observing that, in their case, Marxism-Leninism was not to be interpreted in a "dogmatic" way, but more as the need of a structure for their revolutionary group. ${ }^{60}$

The Italians were also keen to know about Detroit, as very little leaked out in the Italian press about labour unrest in the American cities, "Everybody is asking [for] information about the auto strikes in [the] States", wrote Gambino to Glaberman in $1970 .{ }^{61}$ Visiting Italy at the time of an exploding situation in the factories, Watson observed how the political landscape had been profoundly and quickly altered by the "Hot Autumn". During this second visit he found many more similarities with what was occurring in Detroit, at the moment of the peak influence of the League. He went back to the United States, "insisting that the [American] situation was not substantially different from the Italian, even with its own peculiarities". For their part, the Italians saw in Watson the embodiment of the insurgent spirit of black Americans: he "looked like the son of Malcolm X". ${ }^{62}$ However, Italian radicals also discerned marked parallels with what was occurring in Detroit, which led to the Potere Operaio slogan: "Turin, Detroit, Togliattigrad, class struggle will win". ${ }^{63}$

60. "Intervista con John Watson", in Quaderni Piacentini, A. IX, n. 42 (November 1970), p. 186.

6r. Ferruccio Gambino to Martin Glaberman, 2 October 1970, ALUA, Glaberman Collection, box 9 , folder I.

62. Interview with Ferruccio Gambino, in the possession of the author, September 2008.

63. Ferruccio Gambino, "Only Connect", in Buhle, C.L.R. James, p. 197-198, 198. 
They saw the need to establish a communications channel between two waves of struggle which, though very far apart, were almost synchronized. Bruno Cartosio, a sympathiser of Potere Operaio, later recalled, "It was interesting for us to disseminate our analysis of the American reality, with the aim or the hope of using that analysis to understand also the Italian reality" ${ }^{64}$ Paolo Virno, a former militant, observed that, "Fighting at FIAT of Turin, we were thinking of Detroit, not Cuba or Algiers". ${ }^{\circ}$ s One could even say, not without irony, that "events in the Michigan plants were probably followed more avidly in Turin and other industrial centers than anywhere in the United States" ${ }^{66}$ Watson sold many copies of the League's documentary, Finally Got the Nerws, which even made it to the prestigious independent film festival at Pesaro. ${ }^{67}$

\section{Beyond Detroit and Turin}

In I97I, two different issues of Radical America, the New Left magazine launched by members of the Students for Democratic Society and read nationally by white radicals, covered the almost simultaneous stories of shopfloor dissent and urban protests from Detroit and Turin. The Italian situation, reported the magazine, had "obvious parallels in the US". Contrary to the common American perception of a united European working class, workers in Turin and other industrial centres were divided along regional and political lines, and while some aspects of the "Hot Autumn" were specific to Italy, others related to the American experience:

[...] what can be valuable for American revolutionaries studying the developments in Italy is not so much the circumstances of struggle, but the tactics employed and some of the new ideological positions being formed. [...] Americans seeking to re-establish a militant working class movement in the United States can learn much from the struggles of our Italian comrades. ${ }^{68}$

Were Italian and American radicals right in thinking that the social and industrial conflict headed in similar directions in the two motor cities? They were certainly not blind to the differences. Italian southern immigrants encountered social prejudice, suffered discriminatory practices, and were often depicted as a separate ethnic group, but in the United States entrenched notions of "race" and institutional racism made the predicament of black Detroiters very different. While American radicals could legitimately, if mistakenly, argue that African Americans were comparable

64. Bruno Cartosio, Interview in Futuro Anteriore (interview transcript), p. 6.

65. Branden W. Joseph, "Interview with Paolo Virno", Grey Room, 2I (Fall 2005), p. 27.

66. Georgakas and Surkin, Detroit: I Do Mind Dying, p. 5 I.

67. Ibid, p. I 20.

68. Radical America, 5 (September-October 1971), pp. I, 4, 9. 
to colonial subjects, the same could not apply to southern migrants, whose citizenship rights were never in question.

In the last decade, American historians and social scientists have demonstrated how the policies of the federal government embedded a bias that reinforced inequalities, poverty and unemployment that disproportionally affected African Americans. ${ }^{69}$ Conversely, the policies of the Italian state were more effectively impartial in respect to the regional provenience of the citizens. However, radicals were right in claiming that, in both cases, the inclusion of marginal groups in the Fordist system had "backfired", because these previously unorganized workers were prepared to contest the rules of their subordination as worked out by the companies and the union bureaucracies. It mattered that, notwithstanding the different degree of discrimination, African Americans and southern Italians contested a system that similarly deprived them of a tolerable working environment, political recognition, and dignity.

From the vantage point of I97I, two American developments seemed to prefigure what might have happened in Italy, possibly turning Turin into another Detroit. One was the spreading of the struggle from the factories into the communities where the most deprived workers lived. It was both a realization that the working class did not comprise only industrial workers, but also the unemployed and underemployed, and the recognition that the society that revolved around the Fordist factory affected its dynamics. Italian radicals coined the expression "social factory" to define this phenomenon. Some leaders of the League believed that propaganda in the black community was as important as action in the factories. The League set up a bookshop and a printing shop to disseminate their literature, and cooperated with progressive white organizations. In I97I-I 972 members of the League were at the centre of a protest campaign against the brutal police program STRESS (Stop the Robberies Enjoy Safe Streets), which targeted crime in black neighbourhoods, but resulted in the daily harassment of law-abiding citizens. ${ }^{70}$ The Black Panthers, also covered by the Italian radical press, had famously set up socalled "survival programs" in a number of American cities, such as free breakfasts for children, and ambulance services. In I97I, in the same vein, Lotta Continua had launched a programme in Turin, Milan, and Bologna called prendiamoci la città, "Let's seize the city", with the aim of introducing into the neighbourhoods the same tactics of mass action that had

69. Robert C. Lieberman, Shifting the Color Line: Race and the American Welfare State (Cambridge, 1998); Philip A. Klinker and Rogers M. Smith, The Unsteady March: The Rise and Decline of Racial Equality in America (Chicago, IL, 1999); John David Skrentny, The Ironies of Affirmative Action (Chicago, IL, I996); Paul Frymer, "Race, Labor, and the Twentieth-Century American State", Politics and Society, 32 (2004), pp. 475-509.

70. Georgakas and Surkin, Detroit: I Do Mind Dying, pp. 167-173. 
proved successful in the factories. Radicals called for the picketing of food stores that objected to lowering their prices, for the withholding of fares on public transport (when challenged, workers should tell the conductor to "charge it to Agnelli") and for the occupation - rent-free - of empty apartments and houses. ${ }^{71}$ For Lotta Continua the workers' struggle was to evolve into a "general struggle" - without explicitly saying so, radicals in Detroit harboured the same ambition.

The other lesson that Italian radicals could have learned from Detroit concerned the impact of plant relocation and deindustrialization on the prospects for working-class militancy. In Detroit and other cities in the American Rust Belt, the restructuring of the industrial economy had followed the unionization of the factories in the Mid-West. Detroit's share of American automobile production began to decline irreversibly in the I950s as car manufacturers relocated to other regions of the country, and eventually abroad, to find cheaper workers and weaken the bargaining power of the United Automobile Workers. Decentralization of car production had, by the early i970s, left Detroit in the grip of a diminishing tax base and rising unemployment. ${ }^{72}$ The loss of manufacturing jobs not only had devastating consequences for the city, but also diminished the leverage of radical politics, inside and outside the factories. From 1974, the possibility that Chrysler - the only automaker that remained active in the city - would leave Detroit prompted waves of concessions on wages, benefits, and working hours at every round of contractual negotiations. With the real possibility of plants closing, the UAW quickly brushed off radicals as operating against the interests of the majority of workers. By the end of the I970s, workers were again in a militant mood, but this time in order to make one last, unsuccessful bid to save the plants from closure.

On the other side of the Atlantic, FIAT's management reversed its traditional policy of concentration in the metropolitan area of Turin, where in 1972 three out of four FIAT employees still worked. From I 973 , FIAT established new plants in the lower part of the peninsula in small rural towns such as Cassino, Termoli, Sulmona, and later, Melfi and Termini Imerese in Sicily. ${ }^{73}$ Both unions and radical groups initially looked favourably on the process of decentralization, as they believed that FIAT's plants would spearhead a belated industrialization of the south of Italy. However, these southern plants required relatively few workers as

7I. Bobbio, Storia di Lotta Continua, pp. 84-89; "Verso la lotta generale: Lottiamo per vivere", in Lotta Continua, 2 (February 1972), pp. 2-16.

72. Sugrue, The Urban Crisis, p. I25.

73. Ash Amin, "Restructuring in Fiat and the Decentralization of Production into Southern Italy", in Ray Hudson and John Lewis (eds), Uneven Development in Southern Europe (New York, I995), pp. I 55-2 I0; Fergus Murray, "The Decentralization of Production: The Decline of the Mass-Collective Worker?”, Capital and Class, I (1983), pp. 74-99. 
they were equipped with up-to-date, numerically controlled machines that often assembled pieces made elsewhere; they did not become generators of income nor did they stimulate a subcontracting network of firms. Furthermore, FIAT used decentralization to hit plants such as Mirafiori where radical elements continued to survive: FIAT had made sure that autumn in Turin would never again be "hot".

\section{CONCLUSION}

For almost a generation after World War II, Turinese car makers, trade unionists, and intellectuals were prone to looking at Detroit as if it were a magic mirror that would make clearer the opportunities and intricacies of the future; Detroiters too believed that solutions tried and tested in their city could function in their European counterpart and that the two cities could be moulded in a similar fashion. The deindustrialization of the I 980 s brought to an end this comparative vision, as well as to most of the connections between the "motor cities" (a label now increasingly used in a nostalgic way). It particularly hit the transnational radicals. On both sides of the Atlantic, the prospect of workers' self-organization and control on the shopfloor could obviously only be practised for so long as these cities retained their industrial core. However, in the final analysis, the relocation of automobile plants that followed workers' organization and unrest vindicated the workerists' insight that capital would react to workers insurgency. The struggle between capital and labour was to continue in other places, in other forms, and against a system of production and societal organization altogether transformed by the events of the late i96os. 